\title{
Evaluasi Kinerja PT Bank Perkreditan Rakyat Pesisir Akbar Kabupaten Bima, Nusa Tenggara Barat
}

\author{
Performances Evaluation of PT Bank Perkreditan Rakyat Pesisir Akbar Kabupaten Bima, \\ Propinsi Nusa Tenggara Barat
}

\author{
Raden Rizki Andhitya Yunanto ${ }^{1 *}, \mathrm{Ma}^{\prime}$ mun Sarma ${ }^{2 \sharp}$, dan Darwin Kadarisman ${ }^{3 \sharp}$
}

${ }^{1}$ Kementerian Kelautan dan Perikanan

${ }^{2}$ Departemen Manajemen, Fakultas Ekonomi dan Manajemen, Institut Pertanian Bogor

${ }^{3}$ Departemen Ilmu dan Teknologi Pangan, Fakultas Teknologi Pertanian, Institut Pertanian Bogor

\#Jl. Kamper, Kampus IPB Dramaga, Bogor 16680

\begin{abstract}
ABSTRAK
Masyarakat pesisir terdiri atas nelayan, pembudidaya ikan, pengolah dan pedagang hasil perikanan, pelaku usaha industri dan jasa maritime, serta masyarakat lainnya yang bermukim di daerah pesisir dan pulau-pulau kecil. Bank Perkreditan Rakyar (BPR) Pesisir Akbar di Kabupaten Bima Nusa Tenggara Barat (NTB) adalah salah satu dari keenam BPR Pesisir di Indonesia yang mempunyai salah satu misi mensejahterakan masyarakat pesisir di sekitar wilayah operasionalnya. Kajian bertujuan untuk (1) Mengetahui pengaruh tingkat kinerja finansial dan non finansial PT BPR Pesisir Akbar, (2) Menganalisis faktor-faktor yang berpengaruh terhadap kinerjanya. Evaluasi kinerja PT BPR Pesisir Akbar telah dilakukan dengan baik untuk kinerja keuangan dan non keuangan. Kinerja non keuangan meliputi jumlah dan tingkat kepuasan pelanggan, sedangkan evaluasi keuangan meliputi modal, aset nilai, laba/rugi, ROA (return on assets), CAR (credit adequacy ratio), BOPO (expenses and operating income), NPL (non performing loan), dan LDR (loan to deposit ratio). Hasil evaluasi menunjukkan layanan yang nonkeuangan publik, layanan kredit, dan jasa promosi bersama-sama atau efek nyata secara individual pada kepuasan pelanggan, di mana pelayanan publik adalah faktor terkuat. Evaluasi kinerja keuangan menunjukkan PT BPR Pesisir Akbar relatif baik untuk pengembangan nilai aset, pendapatan, CAR, NPL dan ROA, namun peningkatan modal relatif kecil dan BOPO dan LDR belum baik sampai saat ini.
\end{abstract}

Kata kunci: keuangan, kinerja, pelayanan

ABSTRACT

Coastal communities made up of fishermen, fish farmers, processors and traders of fishery products, businesses and services maritime industry as well as other communities living in coastal areas and small islands. BPR Pesisir Akbar in Bima Nusa Tenggara Barat is one of the six Coastal BPR in Indonesia which has one mission welfare of coastal communities around the operational area. The study aims to (1) Determine the influence of the level of financial and non-financial performance of PT BPR Pesisir Akbar, (2) analyze the factors that affect performance. Performances Evaluation of PT BPR Pesisir Akbar has done well for non-financial and financial performances. Non Financial Performances include the number and level of customer satisfaction, while the financial evaluation includes capital, value assets, profit/loss, ROA (Return On Assets), CAR (Credit Adequacy ratio), BOPO (Expenses and Operating Income), NPL (Non Performing Loan), and LDR (Loan to Deposit ratio). Evaluation results show that non-financial public services, credit services, and promotion services jointly or individually significant effect on customer satisfaction, where public service is the strongest factor. Evaluation of financial performance shows PT. PT. BPR Pesisir Akbar relatively well for the development of asset value, earnings, CAR, NPL and ROA, but the increase is relatively small capital and BOPO and LDR have not been good until now.

Key words: financial, performances, services

*) Korespondensi:

Gd. Mina Bahari I Jl. Medan Merdeka Timur No. 16, Jakarta Pusat 10110 


\section{PENDAHULUAN}

Sumber daya kelautan dan perikanan mempunyai potensi yang besar untuk kemakmuran dan kesejahteraan rakyat Indonesia. Namun potensi tersebut belum dikelola dan dimanfaatkan dengan baik. Salah satu penyebab belum optimalnya pengelolaan tersebut adalah rendahnya mutu sumber daya manusia (SDM) dan lemahnya akses terhadap sumber-sumber pembiayaan bagi masyarakat pesisir.

Masyarakat pesisir yang terdiri atas nelayan, pembudidaya ikan, pengolahan dan pedagang hasil laut, serta masyarakat lainnya yang kehidupan sosial ekonominya tergantung pada sumber daya perikanan dan kelautan, berdasarkan Data BPS tahun 2002 menunjukkan bahwa jumlah desa pesisir di Indonesia adalah 8.090 desa dengan jumlah penduduk 16,24 juta jiwa dan jumlah kepala keluarga (KK) adalah 3,91 juta. Dari hasil olahan yang dilakukan oleh Departemen Kelautan dan Perikanan terhadap data Yayasan Smeru (2004) masyarakat pesisir berjumlah 16,48 juta jiwa. Jumlah ini diperkirakan meningkat mencapai 20 juta jiwa pada tahun 2011 dan tersebar di lebih dari 10.666 desa pesisir di seluruh Indonesia, dengan Poverty Headcount Index (PHI) 0,3214.

Masyarakat pesisir sampai saat ini masih terbelenggu dalam kemiskinan yang terstruktur dalam kurun waktu yang cukup lama, sehingga untuk mengentaskannya dari kemiskinan membutuhkan kerja keras dari pemerintah dan seluruh komponen bangsa Indonesia. Program Pemberdayaan Ekonomi Masyarakat Pesisir (PEMP) dengan sistem peminjaman (Cash Collateral) kepada Bank Pelaksana yang dilaksanakan oleh Direktorat Pemberdayaan Masyarakat Pesisir, Direktorat Jenderal Kelautan, Pesisir, dan Pulau-pulau Kecil, Departemen Kelautan dan Perikanan yang telah berjalan selama 4 tahun yaitu sejak tahun 2004 sampai dengan tahun 2007. Dalam kurun waktu tersebut telah terbentuk sekitar 277 Lembaga Keuangan Mikro (LKM) yang terdapat di seluruh wilayah pesisir di Indonesia. Hal ini tentunya merupakan suatu prestasi yang cukup menggembirakan, karena dengan berdirinya LKM tersebut, maka masyarakat pesisir dapat lebih mudah dalam mengakses dana untuk menambah modal usaha mereka.

Peran lembaga perbankan dalam pemenuhan kebutuhan kredit masyarakat pesisir sampai saat ini masih dirasa kurang maksimal. Lembaga perbankan nasional lebih cenderung untuk memberikan kredit kepada pengusaha-pengusaha besar dengan tingkat risiko yang lebih kecil, sehingga masyarakat pesisir yang masih tergolong ke dalam skala usaha mikro bahkan lebih kecil daripada itu tidak mendapatkan prioritas pelayanan kredit. Upaya yang dilakukan Kementerian Kelautan dan Perikanan untuk meningkatkan akses permodalan untuk masyarakat pesisir telah diwujudkan melalui pembentukan Lembaga Keuangan Mikro (LKM) sejumlah 256 unit yang tersebar di berbagai kabupaten/kota pesisir. Beberapa LKM menunjukkan perkembangan yang cukup baik sehingga bekerjasama dengan PT Permodalan Nasional Madani (PT PNM) dan difasilitasi untuk dikembangkan lebih lanjut menjadi Bank Perkreditan Rakyat (BPR) Pesisir. Sampai saat ini ada enam buah BPR Pesisir yang beroperasi di Indonesia, yaitu di Kabupaten Agam, Pesisir Selatan, Pasuruan, Bima, Lombok Barat, dan Selayar.

Salah satu BPR Pesisir berlokasi di Kabupaten Bima, NTB, berdiri pada tahun 2007 dan diberi nama PT BPR Pesisir Akbar. Kasus pada PT BPR Pesisir Akbar ini dapat memberi gambaran bagaimana kinerja suatu BPR Pesisir yang tumbuh dan berkembang dari LKM yang dibentuk dan dibina oleh Kementerian Kelautan dan Perikanan. Untuk itu perlu kiranya dilakukan evaluasi kinerja pada PT BPR Pesisir Akbar, baik untuk aspek finansial maupun non finansial. Dari hasil evaluasi kinerja ini dapat diketahui kekuatah dan kelemahan yang dapat menjadi masukan untuk perbaikan manajemen PT BPR Pesisir Akbar khususnya dan BPR Pesisir pada umumnya.

Kajian bertujuan untuk (1) Mengetahui pengaruh tingkat kinerja finansial dan non finansial PT BPR Pesisir Akbar, (2) Menganalisa faktor-faktor yang berpengaruh terhadap kinerja PT BPR Pesisir Akbar.

\section{METODE PENELITIAN}

Penelitian ini mengambil obyek BPR Pesisir Akbar di Kabupaten Bima NTB yang mempunyai aset terbesar diantara BPR Pesisir yang lainnya di Indonesia, beralamat di Jalan Lintas Karumbu, Tente, Bima, Nusa Tenggara Barat. Pengumpulan data primer dilakukan untuk mengetahui hal-hal sebagai berikut:
a. Persepsi nasabah tentang kinerja BPR

b. Kelembagaan dan SDM 
Untuk pelaksanaannya dibuat alat bantu kuesioner. Pada prinsipnya, kuesioner dimaksud terdiri atas:

a. Kuesioner untuk nasabah, yang meliputi identitas responden dan persepsi nasabah tentang kinerja BPR.

b. Kuesioner untuk manajer BPR, terdiri atas pertanyaan mengenai kelembagaan dan SDM.

Jumlah responden dapat ditentukan menggunakan rumus Slovin (Umar, 2004) berikut:

$$
n=\frac{N}{1+\left(N e^{2}\right)}
$$

Keterangan :

$\mathrm{N}=$ jumlah populasi

$\mathrm{n}=$ jumlah contoh

$\mathrm{e}=$ derajat kesalahan

Berdasarkan rumus Slovin di atas, dari total nasabah PT BPR Pesisir Akbar Kab. Bima sampai tahun 2010 sebanyak 3500 orang dengan jumlah nasabah yang menggunakan fasilitas peminjaman kredit sebanyak 140 orang, maka jumlah contoh (n) atau jumlah responden yang diambil adalah sebanyak:

$$
\begin{aligned}
n & =\frac{140}{1+\left(140 \times 0,1^{2}\right)} \\
& =58,33 \text { (dibulatkan } 60 \text { orang) }
\end{aligned}
$$

Data sekunder dibutuhkan untuk melengkapi informasi tentang:

1. Laporan keuangan BPRPesisir

2. Keadaan nasabah BPR Pesisir

3. Perkembangan BPR Pesisir

Kepustakaan tentang BPR Pesisir, keadaan alam lokasi penelitian (termasuk buku, jurnal, laporan, dan sebagainya).

\section{Pengolahan dan Analisis Data}

\section{Validitas dan Realibilitas Instrumen}

Pengolahan dan Analisis data kami bagi menjadi 2, yaitu Evaluasi Kinerja Non Finansial dan Evaluasi Kinerja Finansial. Evaluasi Kinerja Non Finansial dengan menguji validitas dan realibilitas kuesioner, menganalisis data dengan analisis regresi parsial dan linear berganda, analisis rataan jumlah nilai atribut per aspek pada kuesioner. Evaluasi Kinerja Finansial dengan menarasikan beberapa hasil analisis keuangan yang didapatkan dari Rencana Kerja Tahun (RKT) 2012 PT BPR Pesisir Akbar. Dengan adanya pemilihan dan batasan ini, diharapkan responden penelitian memiliki keseragaman tinggi.
Untuk menguji validitas instrumen berupa kuesioner dilakukan uji validitas. Valid berarti instrumen tersebut dapat digunakan untuk mengukur apa yang seharusnya diukur. Pengujian menggunakan rumus korelasi produk moment pearson (Arikunto, 2010).

$$
r x y=\frac{n \sum x y-\left(\sum x\right)\left(\sum y\right)}{\ddot{O}\left[n \sum x 2-\left(\sum x\right) 2\right]\left[n \sum y 2-\left(\sum y\right) 2\right]}
$$

Keterangan :

$\mathrm{r} \quad=$ Koefisien korelasi antara peubah $\mathrm{X}$ dan $\mathrm{Y}$

$\mathrm{n} \quad=$ Jumlah contoh

$\mathrm{X}, \mathrm{Y}=$ Skor masing-masing peubah

Reliabilitas kuesioner diuji dengan menggunakan rumus dari teknik Cronbach Alpha yang dapat ditulis sebagai berikut:

$$
\rho_{\alpha}=\frac{N}{N-1} \frac{\sigma_{A}^{2}-\sum \sigma_{i}^{2}}{\sigma_{A}^{2}}
$$

Dimana,

$$
\begin{array}{cl}
\rho_{\alpha} \quad=\text { Reliabilitas instrumen } & \\
& \sum \sigma_{i}^{2}=\text { Jumlah ragam butir } \\
\mathrm{N} \quad= & \text { Banyak butir pertanyaan } \\
& \sigma_{A}^{2}=\text { Ragam total }
\end{array}
$$

\section{Kinerja Finansial}

Evaluasi Kinerja finansial meliputi berbagai indikator yang akan dianalisis, baik untuk tahun terakhir (2011) atau kecenderungan selama lima (lima) tahun terakhir (2007-2011).

1. Modal

Modal merupakan hak atau bagian yang dimiliki oleh pemilik perusahaan yang ditunjukan dalam pos modal (modal saham), surplus, dan laba yang ditahan atau kelebihan nilai aktiva yang dimiliki oleh perusahaan terhadap seluruh hutang-hutangnya (Munawir, 2002: 19).

2. Nilai Aset Total

Aset Total $=$ Kas + Piutang + Simpanan pada Bank lain + Inventaris (bangunan) + Aktiva yang dijaminkan + Biaya dibayar di muka

3. Laba/Rugi

Perkembangan laba/rugi pada PT. BPR Pesisir Akbar merupakan faktor penting penentu peningkatan mutu.

Untuk Menghitung laba rugi perusahaan adalah:

Laba Bersih = Laba Kotor - Beban Usaha 
Beban usaha dalam perusahaan dagang ada dua kelompok.

a. Beban penjualan ialah biaya yang langsung dengan penjualan.

b. Beban administrasi/umum ialah biayabiaya yang tidak langsung dengan penjualan.

4. CAR (Capital Adequacy Ratio)

Rasio ini dapat dirumuskan sebagai berikut (SE BI No 6/73/INTERN DPNP tgl 24 Desember 2004):

$\mathrm{CAR}=\frac{\text { Modal Bank }}{\text { Total Aktiva Tertimbang Menurut Resiko }} \times 100 \%$

Dengan Total Aktiva Menurut Resiko (ATMR) adalah aktiva dalam neraca perbankan yang diperhitungkan dengan bobot persentase tertentu sebagai faktor risiko. Berdasarkan ketentuan Bank Indonesia, bank yang dinyatakan termasuk sebagai bank yang sehat harus memiliki CAR paling sedikit sebesar $8 \%$. Hal ini didasarkan kepada ketentuan yang ditetapkan oleh BIS (Bank for International Settlements).

5. NPL (Non Performing Loan)

Rasio ini dirumuskan sebagai berikut (SE BI No 6/73/INTERN DPNP tgl 24 Desember 2004):

$\mathrm{NPL}=\frac{\text { Total Kredit Bermasalah }}{\text { Total Kredit }} \times 100 \%$

6. ROA (Return on Asset)

Penilaian earning (rentabilitas) menggunakan dua rasio, yaitu Return on Assets (ROA) dan Beban Operasional terhadap Pendapatan Operasional (BOPO). Berikut rumus untuk perhitungan rasio tersebut:
$\mathrm{ROA}=\frac{\text { Laba sebelum pajak }}{\text { Total aktiva }} \times 100 \%$

7. BOPO (Beban dan Pendapatan Operasional) Rasio ini dirumuskan dalam SE BI No. 30/3/UPPB tgl 30 April 1997 sebagai berikut:

$\mathrm{BOPO}=\frac{\text { Biaya operasional }}{\text { Pendapatan operasional }} \times 100 \%$

8. LDR (Loan to Deposit Ratio)

Loan to Deposit Ratio (LDR) adalah rasio antara besarnya seluruh volume kredit yang disalurkan oleh bank dan jumlah penerimaan dana dari berbagai sumber. Berikut rumus mengukur rasio LDR:

$\mathrm{LDR}=\frac{\text { Jumlah Kredit yang diberikan }}{\text { Dana pihak ketiga+KLBI+ Modal Inti }} \times 100 \%$

\section{Kinerja Non Finansial}

1. Jumlah Nasabah

Dinilai jumlah nasabah dan perkembangannya selama 2007-2011

2. Kepuasan Nasabah

Kepuasan nasabah dinilai melalui pelayanan umum, pelayanan kredit dan pelayanan (intensitas) promosi. Untuk masing-masing atribut kinerja pelayanan yang dinilai disajikan pada pada Tabel 1.

Skala yang digunakan dalam pengukuran atribut kinerja ini adalah skala Likert, yaitu skala yang berisi 5 kategori atau tingkat jawaban serta berhubungan dengan pernyataan tentang sikap seseorang (Kinnear and Taylor,1988). Penjabaran masing-masing skala likert seperti pada Tabel 2.

Tabel 1. Atribut kinerja pelayanan pada PT BPR Pesisir Akbar

\begin{tabular}{clll}
\hline No. & \multicolumn{1}{c}{ Pelayanan Umum } & \multicolumn{1}{c}{ Pelayanan Kredit } & \multicolumn{1}{c}{ Pelayanan Promosi } \\
\hline 1 & Pelayanan account officer & Prosedur memperoleh kredit & $\begin{array}{l}\text { Sosialisasi produk } \\
\text { perbankan }\end{array}$ \\
2 & Pelayanan customer service & $\begin{array}{l}\text { Persyaratan agunan/jaminan } \\
\text { pengajuan kredit }\end{array}$ & Intensitas layanan publik \\
& & $\begin{array}{l}\text { Persyaratan administrasi dalam } \\
\text { pengajuan kredit }\end{array}$ & $\begin{array}{l}\text { Upaya pendekatan } \\
\text { langsung }\end{array}$ \\
& Pelayanan Teller & $\begin{array}{l}\text { Lama waktu yang dibutuhkan untuk } \\
\text { pencairan kredit }\end{array}$ & Intensitas hubungan \\
& Fasilitas umum dalam & gedung & Jumlah kredit dari BPR Pesisir Akbar \\
5 & Fasilitas umum di luar & yedung & Pelayanan sosial \\
& &
\end{tabular}


Tabel 2. Skala likert tingkat kepuasan nasabah terhadap kinerja pelayanan PT BPR Pesisir Akbar

\begin{tabular}{clc}
\hline No. & \multicolumn{1}{c}{ Tingkat Kepuasan } & Nilai \\
\hline 1 & Sangat tidak memuaskan & 1 \\
2 & Kurang memuaskan & 2 \\
3 & Cukup memuaskan & 3 \\
4 & Memuaskan & 4 \\
5 & Sangat memuaskan & 5 \\
\hline
\end{tabular}

Untuk mengetahui faktor-faktor yang mempengaruhi kepuasan nasabah terhadap pelayanan yang diberikan PT BPR Pesisir Akbar, digunakan metode Regresi Linear Berganda pada penelitian ini, yaitu tiga peubah bebas (independent variable) dan satu peubah terikat (dependent variable). Peubah bebas $(X)$ dalam penelitian ini terdiri dari $\mathrm{X}_{1}$ adalah pelayanan umum, $\mathrm{X}_{2}$ adalah pelayanan kredit, $X_{3}$ adalah pelayanan promosi. Peubah terikat $(\mathrm{Y})$ adalah kepuasan nasabah. Model matematika pengaruh faktor-faktor utama tersebut adalah:

$$
\hat{\mathbf{Y}}=\mathrm{boo}_{0}+\mathrm{b}_{1} \mathrm{X}_{1}+\mathrm{b}_{2} \mathrm{X}_{2}+\mathrm{b}_{3} \mathrm{X}_{3}
$$

Untuk menganalisis apakah seluruh peubah bebas, yaitu pelayanan umum, pelayanan kredit dan pelayanan promosi secara bersama-sama mempunyai pengaruh terhadap peubah kepuasan nasabah, maka dilakukan tahapan kerja berikut:

1. Menentukan kriteria pengujian hipotesis

$H_{o}: b_{i j}=0$, artinya tidak ada pengaruh positif dan nyata kinerja pelayanan $\left(X_{1}\right)$ terhadap kepuasan nasabah $(\mathrm{Y})$.

$\mathrm{H}_{\mathrm{a}}: \mathrm{b}_{\mathrm{ij}} \neq 0$, artinya ada pengaruh positif dan nyata kinerja pelayanan $\left(\mathrm{X}_{1}\right)$ atau kinerja $\left(\mathrm{X}_{2}\right)$ terhadap kepuasan nasabah (Y).

2. Menentukan taraf nyata, yaitu 0,05 .

3. Kriteria Pengujian

Uji Fhitung

Ho ditolak apabila Fhitung > Ftabel, dengan demikian peubah kinerja pelayanan berpengaruh terhadap kepuasan nasabah.

Ho diterima apabila Fhitung < Ftabel, dengan demikian peubah kinerja pelayanan tidak berpengaruh terhadap kepuasan nasabah.

\section{HASIL DAN PEMBAHASAN}

Kebijakan dan strategi pengembangan PT BPR Pesisir Akbar dari sejak berdirinya tahun 2007 hingga sekarang diarahkan sesuai dengan karakteristik BPR yang berada didalam komunitas ABSIRINDO (Asosiasi Bank Pesisir Indonesia) dibawah payung KKP (Kementerian Kelautan dan
Perikanan) dan Pemerintah Daerah Kabupaten Bima sebagai community bank yang sehat, kuat, produktif serta menyebar di seluruh Indonesia dan fokus dalam penyediaan pelayanan jasa keuangan kepada Usaha Mikro Kecil dan Menengah (UMKM) dan masyarakat setempat khususnya di wilayah pesisir Kabupaten Bima, NTB.

PT BPR Pesisir Akbar memiliki struktur organisasi dari mulai pemegang saham, dewan komisaris, dewan direksi sampai ke bagian penagihan perkreditan yang masing-masing memiliki tugas dan kewenangan sendiri-sendiri. Hingga saat ini PT BPR Pesisir Akbar memiliki jaringan kantor BPR berupa kantor pusat, kantor cabang dan kantor kas dari sejumlah hanya dua kantor kas pada bulan Juni 2009 menjadi enam kantor kas, satu kantor cabang dan dua kantor pos pelayanan pada bulan Mei 2010.

Dalam memberikan layanan pada nasabahnya, PT BPR Pesisir Akbar memiliki beberapa produk unggulan, baik tabungan, kredit dan deposito. Untuk produk tabungan berupa TAMASIR yakni tabungan yang diperuntukkan bagi masyarakat pesisir, TIRAM adalah tabungan untuk masyarakat madani dan TAUHID berupa tabungan Haji dan Umrah. Untuk produk kredit, berupa modal kerja dengan bunga 2,25\% per bulan. Kredit konsumtif dengan bunga $0,1 \%$ per hari atau 3,75\% per bulan efektif 6 hari kerja dalam seminggu. Untuk kredit jaminan emas dengan bunga lebih rendah dari pegadaian, yaitu hanya $2,25 \%$ per bulan.

Sementara kegiatan-kegiatan yang dilakukan PT BPR Pesisir Akbar hingga saat ini tercantum dalam poin-poin berikut:

1. Menyediakan kredit sebagai modal kerja kepada pengusaha mikro salah satunya pada sektor perikanan dengan menerapkan pola Kelompok Pengusaha Mikro dalam pemberian kredit.

2. Menjalin kerja sama dengan lembaga keuangan lain seperti PT PNM (Permodalan Nasional Madani), BNI (Bank Negara Indonesia) 1946, Bank Syariah Mandiri, Jasindo, Bumi Putera Dinas Koperasi, CIMB Niaga, Bank Andara.

3. Melakukan penjualan silang (cross selling) dengan pihak lain dalam bidang usaha furniture dalam bentuk kredit barang/perabot rumah tangga.

4. Melayani jasa transfer (pengiriman dan penerimaan uang) co branding dengan BSM dan BNI Smart, serta melayani pembayaran rekening listrik. 
Selain kegiatan tersebut, upaya yang dilakukan oleh PT BPR Pesisir Akbar untuk meningkatkan daya saing dan jangkauan pelayanan dijabarkan sebagai berikut:

1. Memperkuat Kelembagaan

Kelembagaan industri BPR perlu diperkuat melalui pemberdayaan potensi daerah, peningkatan permodalan BPR, kebijakan yang mendorong penyebaran BPR di seluruh Indonesia, perluasan jaringan kantor dan kerja sama dengan Bank Umum serta lembaga keuangan lain dalam rangka penyaluran kredit kepada UMKM (Linkage Program).

2. Peningkatan Permodalan Bank

Untuk meningkatkan kemampuan BPR dalam melakukan ekspansi dan meningkatkan daya saing, upaya bank tersebut terus dilakukan agar BPR memiliki permodalan yang kuat, jaringan kantor yang lebih terintegrasi dan beroperasi secara efisien, selain daripada itu BPR juga diharapkan dapat memenuhi ketentuan pada waktu yang telah ditetapkan.

3. Perluasan Jaringan Kantor

Dalam rangka meningkatkan daya saing dan memperluas jangkauan pelayanan BPR, Bank Indonesia telah mengeluarkan Paket kebijakan sektor keuangan berupa kemudahan pembukaan Kantor Cabang (KC) BPR, yaitu BPR tidak lagi dibatasi untuk dapat membuka KC dalam setahun. Kemudahan-kemudahan yang ada ditempuh oleh pemerintah demi untuk memperbaiki dan meningkatkan pelayanan kepada masyarakat pengguna jasa.

4. Peningkatan Kerja sama BPR dengan Bank Umum atau Lembaga lain (Linkage Program). Linkage Program merupakan kerja sama Bank Umum dan BPR yang dilandasi semangat kemitraan yang bersifat simbiosis mutualistik dengan tetap berorientasi pada aspek bisnis yang tertuang dalam Generic Model Linkage Program Bank Indonesia. Strategi ini merupakan suatu bentuk kerja sama antara Bank Umum dengan BPR untuk meningkatkan jangkauan dalam rangka penyaluran kredit. Linkage Program dinilai telah memberikan hasil yang positif dalam pengembangan BPR serta peningkatan kredit kepada nasabah. Bank Indonesia berperan dalam memberikan bantuan teknis kepada BPR agar lebih tajam dan faham di dalam menjalin kemitraan dengan mitra linkage.

\section{Uji Validitas Instrumentasi}

Uji validitas berfungsi untuk mengukur valid atau tidaknya kuesioner. Uji ini dilakukan pada setiap butir pertanyaan yang ada pada kuesioner. Instrumen dikatakan valid, apabila mampu mengukur apa yang diinginkan dan dapat mengungkap data peubah yang diteliti secara tepat. Tinggi rendahnya validitas menunjukkan sampai sejauhmana data yang dikumpulkan tidak menyimpang dari gambaran tentang peubah yang diteliti. Untuk mengetahui valid tidaknya pertanyaan dalam kuesioner terlebih dahulu harus dibandingkan dengan $r$ tabel.

- $\quad r$ tabel pada $\alpha 0,05$ dengan derajad bebas (df) = jumlah pertanyaan -2 , pada kasus ini jumlah pertanyaan 10 , jadi $\mathrm{df}=8$.

- $\quad$ r $(0,05 ; 8)$ pada uji satu arah $=0,5494$

Pengambilan keputusan

- Jika $\mathrm{r}$ hitung positif dan $\mathrm{r}$ hitung $>\mathrm{r}$ tabel, maka butir tersebut valid.

- Jika $r$ hitung negatif atau $r$ hitung < $r$ tabel, maka butir tersebut tidak valid.

Dilihat pada Tabel 3, didapatkan nilai $\mathrm{r}$ hitung (dapat dilihat pada kolom Corrected ItemTotal Correlation), semuanya lebih dari $r$ tabel, sehingga dapat disimpulkan bahwa ke 10 pertanyaan tersebut valid.

Tabel 3. Uji validitas

\begin{tabular}{ccc}
\hline No. & $\begin{array}{c}\text { Corrected Item-Total } \\
\text { Correlation }\end{array}$ & Keterangan \\
\hline 1. & 0,614 & \\
2. & 0,664 & \\
3. & 0,675 & \\
4. & 0,749 & Valid $>$ r tabel \\
5. & 0,579 & $(0,549)$ \\
6. & 0,566 & \\
7. & 0,677 & \\
8. & 0,708 & \\
9. & 0,620 & \\
10 & 0,620 & \\
\hline
\end{tabular}

\section{Uji Reliabilitas Instrumentasi}

Nilai-nilai untuk pengujian reliabilitas berasal dari skor pertanyaan yang valid tersebut. Instrumen memiliki tingkat reliabilitas tinggi, jika nilai koefisien yang diperoleh $>0,60$ (Ghozali, 2002). Uji reliabilitas dilakukan dengan melihat cronbach's alpha pada kolom reliability statistics dan cronbach's alpha it item deleted. Nilai cronbach's alpha $0,896>r$ tabel $(0,549)$. Hal ini menunjukkan bahwa hasil pengujian lebih besar dari $r$ tabel, berarti 
bahwa kuesioner tersebut reliabel dapat diandalkan untuk menjadi alat ukur dalam penelitian ini.

Tabel 4. Uji reliabilitas

\begin{tabular}{ccc}
\hline No. & $\begin{array}{c}\text { Cronbach's Alpha It Item } \\
\text { Deleted }\end{array}$ & Keterangan \\
\hline 1. & 0,888 & \\
2. & 0,885 & \\
3. & 0,884 & \\
4. & 0,879 & Reliabel \\
5. & 0,890 & $0,06(\mathrm{r}$ tabel \\
6. & 0,891 & $0,549)$ \\
7. & 0,884 & \\
8. & 0,882 & \\
9. & 0,889 & \\
10 & 0,887 & \\
\hline
\end{tabular}

\section{Karakteristik Nasabah}

Karakteristik nasabah dalam penelitian ini dilihat dari jenis kelamin, usia, pendidikan, penghasilan, seberapa lama usaha yang telah dijalankan, frekuensi melakukan kontak dengan petugas bank, cara melakukan kontak seberapa lama telah menjadi nasabah pembiayaan. Nasabah dominan di Kabupaten Bima adalah pria (53\%). Jenis kelamin merupakan salah satu pedoman dasar dalam melakukan segmentasi pasar, karena perbedaaan jenis kelamin menyebabkan pola perilaku berbeda satu sama lain.

Nasabah sebagian besar berusia di atas 45 tahun (45\%) dan sebagian kecil berusia 25-30 tahun (10\%). Pendidikan dikelompokkan ke dalam tingkatan SLTP, SLTA, Akademi, Sarjana dan Pascasarjana. Responden dengan tingkat pendidikan SMU cukup dominan $(60 \%)$ dan yang paling sedikit adalah sarjana (10\%), sementara untuk lulusan Pascasarjana tidak ada.

Besarnya pendapatan rataan per bulan adalah $73 \%$ yang memiliki pendapatan diatas Rp6 juta, $17 \%$ yang memiliki pendapatan per bulan Rp4-6 juta dan 10\% yang memiliki pendapatan per bulan Rp2-4 juta. Lama menekuni usaha, menunjukkan bahwa $75 \%$ responden memiliki usaha diatas 6 tahun, 18\% antara 4-6 tahun dan $7 \%$ memiliki usaha antara 2-4 tahun.

Sarana Komunikasi antara nasabah pembiayaan dengan petugas Bank dapat dilakukan dengan berbagai cara. Lebih dari setengah responden (52\%) melakukan komunikasi dengan petugas Bank melalui telpon dan sisanya (48\%) datang langsung ke Bank.

Sebanyak $42 \%$ baru menjadi nasabah empat tahun, $23 \%$ tiga tahun, $18 \%$ antara $1-2$ tahun dan
17\%. kurang dari satu tahun. Bila dilihat dari tingkat masalah yang pernah dialami dengan petugas BPR Pesisir Akbar Kabupaten Bima, secara keseluruhan nasabah pembiayaan menyatakan belum pernah menemui masalah dengan para petugas bank, sehingga dapat dikatakan bahwa selama ini hubungan nasabah pembiayoaan dengan para petugas Bank berjalan dengan baik.

\section{Evaluasi Kinerja PT BPR Pesisisr Akbar}

\section{Kinerja Non Finansial}

1. Jumlah dan Penyebaran Nasabah

Nasabah PT BPR Pesisir Akbar sampai akhir tahun 2010, terhitung 3500 orang yang tersebar di seluruh Kabupaten dan Kota Bima. Jumlah nasabah tersebut sudah termasuk nasabah perkreditan 140 orang, deposito 800 orang dan tabungan sebanyak 2.560 orang.

2. Kepuasan Nasabah

a) Aspek Pelayanan Umum

Tingkat kepuasan nasabah terhadap pelayanan umum dapat dilihat pada Tabel 5. Dari Tabel 5 terlihat bahwa tingkat kepuasan tertinggi adalah tingkat pelayanan Costumer Service dengan total rataan $(3,74)$.

b) Aspek Proses Perkreditan

Tingkat kepuasan nasabah terhadap Pelayanan Proses Perkreditan dapat dilihat pada Tabel 6. Dari Tabel 6 terlihat bahwa tingkat kepuasan tertinggi adalah Persyaratan Agunan/Jaminan Pengajuan Kredit dengan total rataan 3,75.

Tabel 5. Tingkat kepuasan nasabah terhadap pelayanan umum pada PT BPR Pesisir Akbar

\begin{tabular}{clc}
\hline No. & \multicolumn{1}{c}{$\begin{array}{c}\text { Kriteria Kepuasan } \\
\text { Nasabah }\end{array}$} & $\begin{array}{c}\text { Skor Tingkat } \\
\text { Kepuasan Rataan }\end{array}$ \\
\hline 1 & $\begin{array}{l}\text { Pelayanan Account } \\
\text { Officer }\end{array}$ & 3,60 \\
2 & $\begin{array}{l}\text { Pelayanan Customer } \\
\text { Service }\end{array}$ & 3,74 \\
3 & Pelayanan Teller & 3,57 \\
4 & Fasilitas umum dalam & 3,37 \\
& gedung & 3,30 \\
5 & Fasilitas umum di luar & \\
\hline & gedung & $\mathbf{3 , 5 2}$ \\
\hline
\end{tabular}


Tabel 6. Tingkat kepuasan nasabah terhadap pelayanan proses perkreditan pada PT BPR Pesisir Akbar

\begin{tabular}{clc}
\hline No. & Kriteria Kepuasan Nasabah & $\begin{array}{c}\text { Skor Tingkat } \\
\text { Kepuasan } \\
\text { Rataan }\end{array}$ \\
\hline 1 & Prosedur memperoleh kredit & 3,62 \\
2 & $\begin{array}{l}\text { Persyaratan agunan/jaminan } \\
\text { pengajuan kredit }\end{array}$ & 3,75 \\
3 & $\begin{array}{l}\text { Persyaratan administrasi } \\
\text { dalam pengajuan kredit }\end{array}$ & 3,58 \\
4 & $\begin{array}{l}\text { Lama waktu yang dibutuhkan } \\
\text { untuk pencairan kredit }\end{array}$ & 3,60 \\
5 & $\begin{array}{l}\text { Jumlah kredit dari BPR pesisir } \\
\text { akbar yang diterima }\end{array}$ & 3,58 \\
\hline \multicolumn{2}{c}{ Total Rataan } \\
\hline
\end{tabular}

c) Aspek Pelayanan Promosi

Tingkat kepuasan nasabah terhadap Pelayanan Promosi dapat dilihat pada Tabel 7. Dari Tabel 7 terlihat bahwa tingkat kepuasan tertinggi adalah intensitas hubungan dengan total rataan terbesar 3,98.

Tabel 7. Tingkat kepuasan nasabah terhadap pelayanan intensitas promosi pada PT BPR Pesisir Akbar

\begin{tabular}{clc}
\hline No. & \multicolumn{1}{c}{$\begin{array}{c}\text { Kriteria Kepuasan } \\
\text { Nasabah }\end{array}$} & $\begin{array}{c}\text { Skor Tingkat } \\
\text { Kepuasan Rataan }\end{array}$ \\
\hline 1 & $\begin{array}{l}\text { Sosialisasi produk } \\
\text { perbankan }\end{array}$ & 3,45 \\
2 & Intensitas layanan publik & 3,60 \\
3 & Upaya pendekatan & 3,95 \\
& langsung & 3,98 \\
4 & Intensitas hubungan & 3,50 \\
5 & Pelayanan sosial bagi & 3,70 \\
& masyarakat pesisir \\
\hline
\end{tabular}

Berdasarkan hasil rataan nilai kriteria ketiga aspek di atas, dapat dilihat bahwa nilai yang terbesar adalah Tingkat kepuasan aspek Promosi $(3,70)$, disusul tingkat kepuasan aspek Perkreditan $(3,63)$ dan yang terendah adalah aspek Pelayanan Umum $(3,52)$. Disamping itu, pada umumnya seluruh kriteria kepuasan masih di bawah skor 4, yang berarti berada antara cukup memuaskan sampai memuaskan. Hasil analisis regresi linear berganda terhadap faktor-faktor yang berpengaruh terhadap kepuasan nasabah PT BPR Pesisir Akbar dapat dilihat pada Tabel 8.

Dari Tabel 8 terlihat bahwa pelayanan umum $\left(\mathrm{X}_{1}\right)$, pelayanan proses perkreditan $\left(\mathrm{X}_{2}\right)$ dan pelayanan promosi $\left(\mathrm{X}_{3}\right)$ secara bersama-sama atau sendiri-sendiri berpengaruh nyata terhadap kepuasan nasabah, karena semua $t$ Hitung $>t$ Tabel dan F Hitung $>$ F Tabel. Selain itu, terlihat bahwa faktor yang paling kuat di antara ketiga faktor yang diamati adalah kepuasan nasabah terhadap pelayanan umum. Untuk pelayanan proses perkreditan dan pelayanan promosi masih berada relatif jauh dibandingkan dengan pelayanan umum, sehingga perlu diprioritaskan dalam program perbaikan kinerja PT BPR Pesisir Akbar. Hasil penelitian Tan \& Wang (2010), bahwa efisiensi meningkatkan keseluruhan kinerja dan pengukuran yang berbeda terhadap efisiensi memiliki hubungan dengan kinerja.

Dari uraian sebelumnya, untuk pelayanan proses perkreditan perlu dititikberatkan terhadap aspek prosedur, jaminan, administrasi, lama waktu pencairan dan jumlah kredit. Untuk faktor pelayanan promosi perlu dititikberatkan terhadap aspek sosialisasi produk, intensitas layanan publik, pendekatan langsung, intensitas hubungan, dan pelayanan sosial.

Tabel 8. Hasil analisis regresi berganda kepuasan nasabah PT BPR Pesisir Akbar

\begin{tabular}{lccc}
\hline \multicolumn{1}{c}{ Variabel bebas } & $\begin{array}{c}\text { Koefisien } \\
\text { Regresi }\end{array}$ & $\begin{array}{c}\mathbf{t} \\
\text { Hitung }\end{array}$ & $\begin{array}{c}\mathbf{t} \\
\text { Tabel }\end{array}$ \\
\hline Konstanta & 0,614 & 2,220 & 2,003 \\
X $_{1}$ (Pelayanan Umum) & 0,535 & 8,777 & 2,003 \\
X $_{2}$ (Pelayanan Proses & 0,139 & 2,467 & 2,003 \\
Perkreditan) & & 2,092 & 2,003 \\
X $_{3}$ (Pelayanan Promosi) & 0,129 & $2,77)$ \\
\hline
\end{tabular}

variabel terikat $=y \quad F$ hitung $=45,668(\mathrm{~F}$ tabel $=2,77)$

$\mathrm{N}=56 \quad \mathrm{R}=0,843 ; \quad \mathrm{R}^{2}=0,710$

Dengan melihat hasil pada Tabel 8, maka persamaan regresinya adalah:

$$
\hat{Y}=0,614+0,535 X_{1}+0,139 X_{2}+0,129 X_{3}
$$

Dimana:

$\hat{Y}=$ Kepuasan nasabah

$\mathrm{X}_{1}=$ Pelayanan Umum

$\mathrm{X}_{2}=$ Pelayanan Proses Perkreditan

$\mathrm{X}_{3}=$ Pelayanan Promosi

Berdasarkan nilai $R=0,843$ dan $R^{2}=0,710$ dapat dinyatakan bahwa model tersebut relatif tepat, tetapi tidak terlalu sempurna karena tidak sangat dekat dengan nilai 1. Dari persamaan regresi tersebut dapat diuraikan beberapa hal berikut:

a. Konstansa (a) $=0,614$, artinya jika pelayanan umum $\left(X_{1}\right)$, perkreditan $\left(X_{2}\right)$ dan intensitas promosi $\left(X_{3}\right)$ nilainya nol, maka hasil kepuasan nasabah $(\mathrm{Y})$ adalah 0,614 . 
b. Koefisien regresi 0,535 , berarti jika pelayanan umum $\left(X_{1}\right)$ mengalami kenaikan 1 unit, hasil output kepuasan nasabah (Y) mengalami peningkatan 0,535 unit.

c. Koefisien regresi 0,139 , berarti jika perkreditan $\left(\mathrm{X}_{2}\right)$ mengalami kenaikan 1 unit, hasil output kepuasan nasabah $(\mathrm{Y})$ mengalami peningkatan 0,139 unit.

d. Koefisien regresi 0,129 , berarti jika intensitas promosi $\left(\mathrm{X}_{3}\right)$ mengalami kenaikan 1 unit, hasil output kepuasan nasabah (Y) mengalami peningkatan 0,129 unit.

Dari hasil perhitungan rataan tingkat kepuasan dan analisis regresi linear berganda, maka perbaikan pelayanan pada BPR Pesisir dapat diprioritaskan pada aspek pelayanan umum dengan total rataan terendah $(3,52)$ dan koefisien regresi tertinggi $(0,535)$ yang berpengaruh nyata terhadap kenaikan tingkat kepuasan nasabah dibandingkan dengan koefisien yang lainnya.

\section{Kinerja Keuangan}

Gambaran aspek keuangan kami dapatkan dari Rencana Kerja Tahun (RKT) 2012 PT BPR Pesisir Akbar yang dibuat pada akhir tahun 2011 dengan menyajikan hasil akhir dalam Tabel 9. Dari Tabel 9, kinerja finansial yang dianalisis melalui dalam tulisan adalah modal, nilai aset, laba/rugi, ROA, CAR, BOPO, NPL dan LDR.

1. Modal dan Aset

Dimulai dari Modal Awal dari dana PEMP, KKP Rp1.479.384.000 pada 1 Oktober 2007. Hal ini ditandai dengan perkembangan aset pada semester yang sama tahun berbeda aset bulan Juni 2008 Rp4.512.848.457 menjadi
Rp9,1 milyar pada bulan Mei 2010 dan pada Bulan Desember 2011 mencapai sekitar Rp20 milyar atau meningkat di atas $200 \%$.

Total aset bank mengalami peningkatan nyata Rp7.667.235.000 (140\%), disebabkan meningkatnya Dana Pihak Ketiga (DPK), simpanan/pinjaman dari bank lain/non bank sebesar Rp2.310.826.000 (356\%) dan tambahan jumlah modal Rp365.892.000 (113\%) juga peningkatan kepercayaan mitra strategis (Linkage Program).

2. Laba/Rugi

Pada awal didirikannya PT BPR Pesisir Akbar tahun 2007 mengalami kerugian Rp38.034.000. Tahun 2008 naik menjadi Rp214.253.000 berikut kenaikan pada tahuntahun selanjutnya sampai akhir tahun 2011 tercatat telah mencapai laba sejumlah Rp1.261.448.000. Rataan persentase per tahun perubahan Laba/Rugi tahun 2007-2011 adalah $61,25 \%$ dan cenderung meningkat pada tiap tahunnya. Hal tersebut menunjukan bahwa secara umum persentase kemampuan mendapatkan laba PT BPR Pesisir Akbar dari tahun 2007-2011 di atas rataan industri perbankan Indonesia, yaitu 26,73\% per tahun (Bank Indonesia, 2010).

3. ROA

Rasio-rasio pada penelitian dibandingkan dengan ROA sebagai variabel dependen yang mencerminkan kemampuan manajemen bank, karena ROA mengukur efektivitas perusahaan dalam menghasilkan pendapatan atau keuntungan dari pengelolaan aset dan efisiensi manajerial secara keseluruhan. ROA

Tabel 9. Perkembangan kinerja keuangan (dalam ribu rupiah) dan rasio keuangan PT BPR Pesisir Akbar Tahun 2007-2011

\begin{tabular}{|c|c|c|c|c|c|c|c|}
\hline No & Komponen & 2007 & 2008 & 2009 & 2010 & 2011 & $\begin{array}{c}\text { Persentase rataan } \\
\text { perubahan }\end{array}$ \\
\hline 1 & Asset & 1.774 .926 & 4.003 .303 & 7.343 .658 & 11.793 .962 & 20.088 .192 & 45,00 \\
\hline 2 & Kredit & 1.252 .722 & 3.436 .839 & 5.468 .152 & 9.122 .009 & 12.105 .057 & 41,00 \\
\hline 3 & Tabungan & 116.990 & 795.329 & 2.672 .558 & 2.816 .706 & 3.827 .593 & 46,50 \\
\hline 4 & Deposito & 197.000 & 793.900 & 1.056 .500 & 1.529 .000 & 3.260 .750 & 46,00 \\
\hline 5 & Laba/rugi & $-38,034$ & 214,253 & 528,356 & 673,973 & $1,261,448$ & 61,25 \\
\hline 6 & Modal bank & 1.479 .384 & 1.405 .884 & 1.540 .884 & 1.889 .490 & 2.019 .607 & 6,75 \\
\hline 7 & CAR & $103.97 \%$ & $39.97 \%$ & $38.76 \%$ & $24.00 \%$ & $21.56 \%$ & $-21,50$ \\
\hline 8 & NPL & $0.00 \%$ & $0.49 \%$ & $0.60 \%$ & $0.68 \%$ & $0.60 \%$ & 15,00 \\
\hline 9 & ROA & $69.88 \%$ & $84.25 \%$ & $69.97 \%$ & $94.09 \%$ & $80.35 \%$ & 2,62 \\
\hline 10 & $\mathrm{BOPO}$ & $135.36 \%$ & $78.52 \%$ & $64.29 \%$ & $74.32 \%$ & $55.31 \%$ & $-20,01$ \\
\hline 11 & LDR & $69.88 \%$ & $96.39 \%$ & $84.20 \%$ & $118.50 \%$ & $71.73 \%$ & 0,46 \\
\hline
\end{tabular}

Sumber: Rencana Kerja Tahun 2012 PT BPR Pesisir Akbar, 2011. 
yang menjadi salah satu rasio margin laba, menunjukkan bagian penjualan yang melebihi biaya (baik biaya variabel maupun biaya tetap). Semakin besar ROA menunjukkan kinerja perusahaan semakin baik, karena tingkat return semakin besar, aktiva perusahaan lebih cepat berputar untuk menjamin kerangka keuangan yang memungkinkan pertumbuhan perusahaan perbankan.

Jika kita lihat pada Tabel 11, pergerakan ROA fluktuasi perubahan rataan adalah 2,62\% per tahun dengan berkisar pada poin $10 \%-20 \%$ untuk yang tertinggi, yaitu pada periode 2010 hingga poin $15 \%$ untuk yang terendah yaitu pada periode awal 2007, dimana standar terbaik untuk angka ROA adalah 1,5\% (Infobank, 2007). Jika diamati lebih kritis, pada periode pergantian tahun, yaitu dari 2010 ke 2011, ROA cenderung menurun.

\section{CAR}

Bila dilihat dari sisi permodalan yang direfleksikan dengan ratio CAR, dapat disimpulkan bahwa pergerakan CAR cenderung mencapai angka tertinggi $103,97 \%$ pada periode 2007 yang mengalami penurunan ke angka terendah 21,56\% pada periode 2011 dengan rataan persentase penurunan $21.50 \%$ per tahun. Memang secara umum ratio CAR yang dicapai PT. BPR Pesisir Akbar memenuhi persyaratan, yaitu ratio CAR lebih dari $8 \%$, tetapi jika fluktuasi CAR kita bandingkan dengan fluktuasi pada ratio ROA, pergerakan turunnya ratio $\mathrm{CAR}$ sangat tajam dibanding pergerakan ratio ROA. Ada beberapa periode dimana pergerakan CAR berbanding terbalik dengan pergerakan ROA, yaitu pada periode 2007-2008 dan 2009-2010 (Tabel 9). Hal ini bertentangan dengan teori yang ada, dimana jika rasio CAR meningkat, maka seharusnya ROA juga mengalami peningkatan (Infobank, 2007).

\section{4. $\mathrm{BOPO}$}

Hal serupa juga terjadi pada tingkat efisiensi operasi perbankan, dimana perolehan BOPO dari 2007 sampai 2011 tidak menentu arahnya atau cenderung menurun. Fenomena yang terjadi ini tidak sesuai dengan teori yang ada, dimana seharusnya hubungan antara BOPO dengan ROA adalah berbanding terbalik. Angka terbaik untuk rasio BOPO adalah dibawah 90\% (Infobank, 2007), jika rasio BOPO yang dihasilkan suatu bank melebihi $90 \%$, dapat disimpulkan bahwa bank tersebut tidak efisien dalam menjalankan operasinya. Jika rasio BOPO berada pada kondisi efisien, laba yang diperoleh akan semakin besar karena biaya operasional yang ditanggung bank semakin kecil. Ang et al. (2000), Fleming et al (2005) dan Chow \& Yuk (2005), adanya hubungan yang negatif antara kepemilikan manajerial dengan rasio biaya (biaya operasional terhadap penjualan), artinya dengan kepemilikan manajerial maka semakin tinggi tingkat efisiensi perusahaan.

Dengan meningkatnya laba, maka dapat dipastikan rasio ROA juga meningkat. Dari Tabel 9. menunjukkan bahwa rataan penurunan 20,01\% per tahun dengan rasio BOPO yang melebihi angka $90 \%$ terjadi pada periode awal 2007 dimana angka rasio BOPO mencapai $135,36 \%$, kemudian pada periode selanjutnya rasio BOPO kembali pada angka di bawah 90\% dengan pergerakan yang berfluktuasi disekitar angka 78,52\% hingga $55,31 \%$. Tetapi jika diamati lebih teliti lagi dalam kaitannya dengan pergerakan rasio ROA, maka kita dapat simpulkan bahwa dalam fluktuasinya, arah pergerakan kedua rasio ini sering terlihat searah. Hal ini bertentangan dengan teori yang ada, dimana jika rasio BOPO meningkat, maka seharusnya ROA juga mengalami penurunan.

5. NPL

Fenomena antar rasio-rasio keuangan juga terjadi terhadap NPL dan hubungannya dengan ROA, dimana seharusnya mempunyai hubungan yang berbanding terbalik. Dari Tabel.11. dapat dilihat bahwa penurunan NPL tidak diiringi dengan kenaikan ROA. Dari 2010 ke 2011, angka NPL mempunyai kecenderungan menurun dari angka $0,68 \%$ pada periode 2010 hingga angka 0,60\% pada periode 2011. Secara umum dapat disimpulkan bahwa rasio NPL PT BPR Pesisir Akbar pada periode tersebut semakin baik karena pada periode terakhir, yaitu 2011 rasio NPL berada pada angka $0,60 \%$ dimana angka terbaik untuk rasio NPL adalah di bawah 5\% (Infobank, 2007). Dengan kata lain kredit bermasalah yang dihadapi PT BPR Pesisir Akbar pada periode tersebut semakin kecil. Akan tetapi pergerakan NPL yang semakin baik (angka rasio semakin kecil) ini tidak diimbangi dengan semakin meningkatnya rasio ROA. Pada periode penelitian (2007-2011) terlihat bahwa pergerakan $\mathrm{ROA}$ berfluktuasi, sehingga hal tersebut 
tidak sesuai teori yang berlaku dimana penurunan NPL seharusnya disertai dengan peningkatan ROA.

6. LDR

Pada pergerakan rasio LDR, dari Tabel 11 terlihat terjadi fluktuasi kenaikan angka LDR untuk periode 2007 dengan angka 69,88\% hingga 2008 dengan angka 96,39\%, kemudian pada periode 2009 hingga 2010 yaitu dari angka $84,20 \%$ menjadi $108,50 \%$. Untuk periode 2010-2011, fluktuasi yang terjadi angka rasio LDR menurun berkisar antara 108,50\% hingga $71,73 \%$. Standar terbaik untuk LDR menurut Bank Indonesia adalah $80 \%$ hingga $110 \%$ sesuai dengan Peraturan BI Nomor 5/20/P.BI/ 2003, sehingga dapat disimpulkan secara umum dari periode 2007 hingga 2011, rasio LDR yang memenuhi standar Bank Indonesia hanya dapat dicapai pada periode 2008-2010. Jika kita kaitkan lagi dengan ROA, maka akan jelas terlihat bahwa pergerakan LDR terhadap ROA tidak beraturan dan berfluktuatif. Hal ini tidak sesuai dengan teori, dimana seharusnya hubungan LDR dengan ROA berbanding lurus.

\section{KESIMPULAN}

Evaluasi kinerja non finansial berdasarkan hasil analisis regresi menunjukkan bahwa pelayanan umum, pelayanan proses perkreditan dan pelayanan promosi secara bersama-sama dan sendiri-sendiri berpengaruh nyata terhadap kepuasan nasabah. Selain itu, terlihat bahwa faktor paling kuat dari ketiga faktor yang diamati adalah kepuasan nasabah terhadap pelayanan umum.

Berdasarkan hasil total rataan nilai atribut ketiga aspek Pelayanan Umum, Pelayanan Proses Perkreditan, dan Pelayanan Promosi, nilai kepuasan nasabah yang terbesar adalah aspek pelayanan promosi $(3,70)$ diikuti aspek pelayanan kredit $(3,63)$ dan yang terendah adalah aspek pelayanan umum $(3,52)$. Berdasarkan skala Likert (1-5), nilai rataan tersebut berada pada kisaran skor 3-4, yaitu masuk pada kriteria cukup memuaskan sampai dengan memuaskan.
Evaluasi kinerja keuangan menunjukkan bahwa peningkatan nyata serta penurunan sangat terlihat dengan kemampuan mendapatkan laba dengan rataan persentase per tahun $61,25 \%$ PT BPR Pesisir Akbar dari tahun 2007-2011 di atas rataan industri perbankan Indonesia, yaitu 26,73\% per tahun (Bank Indonesia, 2010). Hal ini dapat menjadi salah satu kekuatan dan strategi untuk terus meningkatkan mutu pelayanan terutama pada aspek keuangan di PT BPR Pesisir Akbar.

\section{DAFTAR PUSTAKA}

Ang, J.S., Rebel, A. C. \& Lin, J.W. 2000. Agency Costs and Ownership Structure. The Journal of Finance, 55 (1): 81-106.

Arikunto, S. 2010. Prosedur penelitian: Suatu Pendekatan Praktik. Rineka Cipta, Jakarta.

Bank Indonesia. 2010. Krisis Global dan Penyelamatan Sistem Perbankan Indonesia. Bank Indonesia, Jakarta.

BPS. 2009. Hasil Survei Sosial Ekonomi Nasional Tahun 2008 Kabupaten Bima. Bima: BPS.

Chow, S. \& Yuk, J. 2005. Agency Cost and Ownership Structure: Evidence from Small Business Finance Survey Data Base. Small Business Research Summary, 268: 1-31.

Departemen Kelautan dan Perikanan. 2009. Buku Profil Bank Perkreditan Rakyat Pesisir. Jakarta

Departemen Kelautan dan Perikanan. 2009. Buku Profil Kegiatan Usaha Mikro. Jakarta.

Fleming, G., Heaney, R., \& McCosker, R. 2005. Agency Cost and Ownership in Australia, Pasific-Basin Finance Journal, 13: 29-52.

Info Bank No. 343. Oktober 2007. Perang Rebutan Pasar di Tengah Konsolidasi yang Melelahkan: hlm. 13.

Kementerian Kelautan dan Perikanan, 2010, SOP Asosiasi BPR Pesisir, Jakarta.

Kinnear, Thomas C, and James R Taylor. 1988. Riset Pemasaran. Dialih bahasakan oleh Yohames Lamarto. Erlangga, Jakarta.

PT BPR Pesisir Akbar. 2011. Rencana Kerja Tahun 2012.

Tan, J. \& Wang, L. 2010. Flexibility-Efisiensi Trade off and Performance Implication among Chines SOEs. Journal of Business Research, 63: 356-362.

Umar, H. 2004. Metode Penelitian Untuk Skripsi Dan Tesis Bisnis. PT RajaGrafindo Persada, Jakarta. 